\title{
ODPOWIEDŹ ŚW. TOMASZA Z AKWINU NA WSPÓŁCZESNĄ UTRATĘ ŚWIADOMOŚCI GRZECHU
}

\section{Wstęp}

Współcześnie, zwłaszcza w Europie, a coraz wyraźniej także w Polsce można zaobserwować postępującą fragmentaryzację społeczną i pogłębiającą się w szybkim tempie sekularyzację. Oba te procesy spowodowały znaczący spadek znaczenia autorytatywnych źródeł moralności, takich jak rodzina, szkoła i Kościół. Jednym ze skutków tego osłabienia jest rosnąca akceptacja, okazywana głównie w środkach masowego przekazu, dla różnego typu niekiedy mocno już wynaturzonych postaw i zachowań, w czym należałoby widzieć jeden z najbardziej negatywnych przejawów narastającej sekularyzacji ${ }^{1}$. Oznacza to, że współczesny człowiek przestaje poszukiwać niezmiennych norm moralności, które kształtowały społeczeństwa europejskie przez stulecia, ponieważ sam dla siebie staje się ich wyznacznikiem. W Adhortacji apostolskiej Reconciliatio et paenitentia Jan Paweł II, podążając za swoim poprzednikiem, Piusem XII, profetycznie zapowiadał, że dramatem czasów współczesnych będzie utrata poczucia grzechu². Podkreślał, że owo poczucie jest integralnie związane ze świadomością moralną, która z kolei ma swoje źródło w więzi łączącej człowieka z Bogiem, gdyż prawo moralne jest zakorzenione w wieczystym prawie Bożym ${ }^{3}$. W tym sensie świadomość grzechu jest jak gdyby termometrem wskazującym kondycję wiary współczesnego człowieka. Im słabsza jest ta kondycja, tym bardziej znikoma jest owa świadomość. Żadnej krytycznej refleksji nad współczesną moralnością nie może umknąć owa zależność, że stale pogłębiający się kryzys moralny, którego współcześni ludzie są naocznymi świadkami, jest bezpośrednio związany z kryzysem wiary, z narastającą sekularyzacją społeczeństwa.

Jakie są jednak szersze uwarunkowania tego zjawiska w obecnych czasach? Z pewnością składa się na nie wiele czynników i przyczyn. Niniejszy artykuł jest

1 S. Gaworek, Utracony blask, Warszawa 2011, s. 13.

2 Jan Paweł II, Reconciliatio et paenitentia, w: Adhortacje Jana Pawła II, t. 1, Kraków 1996, s. 226.

3 „Światło rozumu naturalnego, dzięki któremu rozróżniamy dobro od zła, co jest rzeczą prawa naturalnego, będącego niczym innym jak wrażeniem w nas światła Bożego. Stąd też jest jasne, że prawo naturalne jest niczym innym jak istniejącym udziałowo w rozumnym stworzeniu prawem wiecznym". Tomasz z Akwinu, Suma teologiczna, t. 13, Prawo, London 1986, s. 20-21. 
próbą przyjrzenia się bliżej temu niepokojącemu procesowi. Jego celem jest wskazanie i wyjaśnienie źródeł stale narastającej sekularyzacji oraz związanej z nią utraty świadomości grzechu, jak również zaproponowanie - na gruncie doktryny św. Tomasza z Akwinu - środków zaradczych, które mogłyby odwrócić niekorzystne tendencje. Omawianą tutaj problematyką zajmowali się dotychczas przede wszystkim papieże XX i XXI w., np. Pius XII w encyklice Summi pontificatus oraz Jan Paweł II w przytoczonej adhortacji Reconciliatio et paenitentia i w dokumencie Ecclesia in Europa, a także współcześni myśliciele i filozofowie, jak chociażby prof. Roberto de Mattei w książce Dyktatura relatywizmu.

\section{Kryzys wiary - samowystarczalność czlowieka}

Poszukując przyczyn postępującego kryzysu wiary, który wydaje się zjawiskiem powszechnym, tak naprawdę poszukuje się odpowiedzi na pytania: Do czego dąży współczesny człowiek? Dlaczego Bóg przestaje być dla człowieka celem owych dążeń. Zapewne jedną z głównych przyczyn zjawiska, które stanowi założenie drugiego pytania, jest pokusa samowystarczalności. Joseph Ratzinger, będąc jeszcze kardynałem, opisał ten fenomen w książce Bóg $i$ świat. Zauważył m.in.: „Niewątpliwie żyjemy w okresie, gdy pokusa, by działać bez Boga, urosła do niebywałych rozmiarów. Nasza cywilizacja techniki i dobrobytu opiera się na przekonaniu, że w zasadzie wszystko można wytworzyć. Gdy tak uważamy, życie zaczynia się zamykać w granicach rzeczy, które potrafimy wytworzyć, realności, których istnienia potrafimy dowieść. Pytanie o Boga odchodzi więc w niepamięć"4. Można więc stwierdzić, że przyszły papież przyczyny kryzysu duchowego, który rodzi indyferentyzm religijny, a nawet skutkuje postawami ateistycznymi, upatruje w postępie techniki i dobrobycie, dających ludziom złudne przekonanie o ich samowystarczalności. Jeżeli zatem człowiek w logice owej pokusy dochodzi do przekonania, że jest w stanie wszystko wytworzyć, wówczas Bóg staje się zbędnym dodatkiem życiowym, gdyż nie znajduje miejsca w subiektywnej gradacji potrzeb człowieka. Wówczas w miarę postępu owej autarkicznej mentalności oczywistością staje się pogląd, że to, czego człowiek sam nie wytworzy, nie istnieje ${ }^{5}$. Jego logiczną konsekwencją jest przekonanie, że szczęście, czyli samospełnienie się istoty ludzkiej, jest produktem, który można wytworzyć. To przekonanie z kolei sprawia, że wielu ludzi ucieka się do pewnych form religii, które na pozór obywają się bez wiary, a wśród nich na pierwszym miejscu należy wymienić różne formy ezoteryzmu, które nierzadko oznaczają pewną technikę osiągania szczęścia ${ }^{6}$. Tego typu sposoby samorealizacji stają się współczesnym ideałem życia, ponieważ pozwalają żyć ze sobą w zgodzie, nie stawiają wymagań i nie domagają się gruntownej przemiany życia. Pokusa samowystarczalności prowadzi

4 J. Ratzinger, Bóg i świat, tłum. G. Sowinski, Kraków 2005, s. 23.

5 J. Ratzinger, Bóg $i$ świat, dz. cyt., s. 23.

6 J. Ratzinger, Bóg $i$ świat, dz. cyt., s. 24. 
więc człowieka do przekonania, że jest on w stanie sam zaspokoić swoje najgłębsze potrzeby i pragnienia, zatrzymując się na tym, co jest produktem jego twórczości. W tym sensie Bóg staje się wielkim nieobecnym, a wiara jawi się jako mglista, mało realna rzeczywistość, której nie warto poświęcać uwagi.

Mentalność autarkiczna będąca bezpośrednią przyczyną sekularyzacji pociąga za sobą kolejne konsekwencje pogłębiające wspomniany kryzys. Otóż jeżeli człowiek jest samowystarczalny, a więc sam wytwarza przedmiot swojego spełnienia, wówczas redukuje swoje potrzeby do tego, co stworzone. W tym sensie materia, ów produkt wytwórczy człowieka, staje się dla niego bożkiem. Z kolei materialistyczna wizja rzeczywistości prowadzi do określonych postaw i zachowań konsumpcjonistycznych. Innymi słowy, spełnienie osiąga ten, kto więcej posiada i konsumuje. We wspomnianej we wstępie adhortacji Jan Paweł II tak opisywał to zjawisko: „«Sekularyzm», który w swej naturze i definicji jest zespołem poglądów i zwyczajów broniących humanizmu całkowicie oderwanego od Boga i całkowicie skoncentrowanego na kulcie działania i produkcji, wypaczonego przesytem konsumpcji i przyjemności, nie troszczy się o niebezpieczeństwo «utraty własnej duszy», nie może nie zagrażać poczuciu grzechu. To zagrożenie będzie sprowadzać się coraz bardziej do tego, co obraża człowieka. Ale właśnie tu narzuca się gorzkie doświadczenie [...], że człowiek może zbudować świat bez Boga, ale ten świat obróci się przeciwko człowiekowi"’.

Zredukowana wizja rzeczywistości oraz troska o zaspokojenie potrzeb czysto materialnych prowadzi współczesnego człowieka do swoistego rodzaju zaślepienia. Nie dostrzega on potrzeby otwarcia się na wartości duchowe, gdyż cała jego uwaga jest skupiona na dążeniu do konsumpcji i zwiększenia przyjemności. Zamyka więc człowieka w tym, co tylko zmysłowe. Do takich postaw zdecydowanie przyczynia się dzisiaj skrajnie liberalna logika gospodarki rynkowej, która widzi w ludziach wyłącznie konsumentów. Reklamy i działania marketingowe zawierają odpowiednio silne komunikaty perswazyjne, rozbudzają pragnienie posiadania nowych rzeczy, które często nie mają istotnej wartości użytkowej, lecz są jedynie kolejnymi gadżetami ${ }^{8}$. Już w 1948 r. o hipnotycznej, zniewalającej mocy reklamy pisał w książce Ucieczka od wolności Erich Fromm: „Ogromna część nowoczesnej reklamy nie przemawia do rozumu, lecz od emocji. Podobnie jak każdy inny rodzaj sugestii hipnotycznej stara się oddziaływać na swoje obiekty uczuciowo, by potem ujarzmić je intelektualnie. Ten typ reklamy korzysta ze wszelkich możliwych środków do wywarcia wrażenia na nabywcy: powtarzanie w kółko tej samej formuły; odziaływanie za pomocą sugestywnego obrazu, przedstawiającego np. wytworną damę albo słynnego boksera palących określony gatunek papierosów; wabienie klienta, a jednocześnie osłabienie w nim krytycyzmu wizerunkiem ładnej dziewczyny z sex

Jan Paweł II, Reconciliatio et paenitentia, art. cyt., s. 226.

8 R. Heath, Ukryta moc reklamy. Co tak naprawdę wphywa na wybór marki?, thum. A. Nowak, Gdańsk 2006, s. 92-95. 
appealem; terroryzowanie go groźbą «niemiłego zapachu» lub «nieświeżego oddechu» albo, przeciwnie, podsycanie w nim marzeń o rozstrzygającej zmianie w życiu dzięki nabyciu określonej koszuli albo mydła. Wszystkie te metody są z zasady irracjonalne i nie mają nic wspólnego z jakością towaru; tłumią i zabijają zmysł krytyczny nabywcy, działając jak narkotyk lub hipnoza". W ten sposób kupowanie i konsumpcja stały się podstawową rozrywką człowieka współczesnego, a nawet zdaniem niektórych - nową religią. Argumentów przemawiających za tą tezą nie trzeba szukać zbyt daleko, wystarczy wejść, najlepiej w sobotę lub w niedzielę, do jakiegokolwiek centrum handlowego. Tłumy kupujących to pierwsza rzecz, jaka się rzuca w oczy. Świat staje się coraz bardziej opanowany przez rynek. Benjamin Barber w jednej ze swoich publikacji pt. Skonsumowani pokazuje, że w pogoni za zyskiem współczesne gospodarki krajów rozwiniętych coraz bardziej koncentrują się nie tyle na zaspokajaniu potrzeb, ile na ich wzbudzaniu, wykorzystując w tym celu różne techniki perswazji ${ }^{10}$. W efekcie moc coraz bardziej nieokiełznanego konsumpcjonizmu wydaje się odwracać sens słów Jezusa, które przytacza św. Paweł: „Więcej szczęścia jest $w$ dawaniu aniżeli w braniu" (Dz 20, 35).

Podsumowując, należy stwierdzić, że za wyżej opisaną dominacją konsumpcyjnego stylu życia kryje się - niekiedy zakamuflowana - antyspirytualistyczna koncepcja natury ludzkiej. Jej zwolennicy nie uznają istnienia w człowieku sfery duchowej. Przekonanie to prowadzi w konsekwencji do nadania prymatu temu, co materialne. Pytanie o Boga wydaje się niepotrzebne, ponieważ to właśnie konsumpcja, nieograniczona wyższymi wartościami, staje się swoistą nową religią, która ma za zadanie zaspokoić głód Boga, który jest wpisany w naturę każdego człowieka.

\section{Przyczyny zaniku świadomości grzechu}

Opisany wyżej kryzys wiary skutkujący często przyjęciem materialistycznej, zredukowanej wizji człowieka, rodzi kolejne negatywne konsekwencje o doniosłym znaczeniu dla rozległych dziedzin życia. Jednym z takich skutków jest utrata świadomości grzechu. Jeżeli bowiem, jak to już zostało powiedziane, poczucie grzechu bezpośrednio wiąże się z osobą Boga, to niejako naturalną koleją rzeczy jest to, że postępująca sekularyzacja powoduje utratę poczucia grzechu. Jeżeli Bóg nie znajduje miejsca $\mathrm{w}$ życiu społeczeństw, to i pojęcie grzechu odchodzi stopniowo w zapomnienie. Na utratę tej świadomości składa się jednak jeszcze wiele innych czynników.

9 E. Fromm, Ucieczka od wolności, tłum. O. i A. Ziemilscy, Warszawa 2008, s. 130-131.

10 B. Barber, Skonsumowani, thum. H. Jankowska, Warszawa 2009, s. 196. 


\section{Dyktatura relatywizmu: ,ja i jego zachcianki”}

We wstępie - powołując się na św. Tomasza z Akwinu - stwierdzono, że poczucie grzechu jest bezpośrednio związane ze świadomością moralną, zakorzenioną $\mathrm{w}$ wieczystym prawie Bożym. Prawo moralne bowiem jest prawem obiektywnym, wpisanym przez Boga w samą rozumną naturę człowieka ${ }^{11}$. Dlatego w prawie ludzkim - jak podkreśla Akwinata - nic nie może być usankcjonowane, jeżeli odbiega od prawa wiecznego ${ }^{12}$. Stąd prawo Starego Przymierza, którego fundamentem jest Dekalog przekazany przez Boga Mojżeszowi na górze Synaj, nie zostało zniesione, lecz wypełnione przez prawo Ewangelii. Tak więc Jezus nie przyszedł, by znieść prawo naturalne, lecz by je „wypełnić” (Mt 5, 17), czyli doprowadzić do pełni ${ }^{13}$. W tym sensie człowiek dzięki możliwościom swojego rozumu może te prawa odczytać i do nich się stosować. Jednak kryzys wiary prowadzi do zakwestionowania istnienia prawa wiecznego, a tym samym całego porządku moralnego. O tej zależności mówił również w 1991 r. w Krakowie Jan Paweł II: „Dla człowieka przy końcu XX stulecia program brzmi: «Żyjmy tak, jak gdyby Bóg nie istniał». Jednak jeśli Bóg nie istnieje, wszystko wolno - stwierdził już Dostojewski. Jesteśmy poza dobrem i złem - dopowiada Nietzsche. Kiedy wiek XX zbliża się ku końcowi, mamy za sobą doświadczenia aż nazbyt wymowne i straszliwe, które świadczą o tym, co w rzeczywistości oznacza ten nietzscheański program. Ku czemu idziemy, żyjąc tak, jakby Bóg nie istniał?"14.

Tak więc negując istnienie Boga, odrzuca się tym samym istnienie obiektywnego prawa naturalnego, a także kwestionuje fakt, że ludzka natura jest trwała i stabil$n a^{15}$. Jeżeli zaś przyjąć, że nie istnieje niezmienna natura ludzka, niezależna od miejsca i czasu, nie można również mówić o fundamentalnych prawach, które należy respektować. Taki sposób postrzegania rzeczywistości skutkuje utratą świadomości moralnej i prowadzi do zachowań i postaw relatywistycznych. „Skoro człowiek sam, bez Boga, może stanowić o tym, co jest dobre, a co złe, może też zdecydować, że

11 Por. Tomasz z Akwinu, Suma teologiczna, t. 13, dz. cyt., s. 21. „Nihil est aliud quam participatio legis aeternae in rationali creatura".

12 Por. Tomasz z Akwinu, Suma teologiczna, t. 13, dz. cyt., s. 42.

13 R. de Mattei, Dyktatura relatywizmu, thum. P. Toboła-Pertkiewicz, E. Turlińska, Warszawa 2009, s. 45.

14 Jan Paweł II, Homilia w czasie Mszy św. beatyfikacyjnej Anieli Salawy, odprawionej na Rynku Głównym (Kraków, 13 sierpnia 1991), opoka.org.pl/biblioteka/W/WP/jan_pawel_ ii/homilie/50krakow_13081991.html [dostęp: 28 IX 2020 r.].

15 „Najgłębszym i ostatecznym powodem zła dręczącego dzisiejsze społeczeństwa jest zaprzeczenie i odrzucenie jednakowej i wspólnej wszystkim normom prawości obyczajów, zarówno w prywatnym życiu poszczególnych ludzi, jak i w stosunkach państwowych i międzypaństwowych, mianowicie prawa natury, które zostało zlekceważone i zapomniane. A prawo to ma przecież za swój fundament samego Boga”. Pius XII, Summi pontificatus, Warszawa 1998, s. 15. 
pewna grupa ludzi powinna być unicestwiona"16. Jeżeli zatem grzech jest wykroczeniem przeciwko prawu wiecznemu ${ }^{17}$, to w świetle owej relatywistycznej mentalności trudno mówić o świadomości moralnej czy też o poczuciu grzechu, skoro człowiek sam dla siebie staje się arbitrem w dziedzinie porządku moralnego.

Kard. J. Ratzinger podczas Mszy Świętej poprzedzającej wybór papieża, odprawionej 18 kwietnia 2005 r., chcąc oddać ducha współczesnej epoki, mówił: „Ileż powiewów nauki przyniosły nam ostatnie dziesięciolecia, ileż nurtów ideowych, ile modnych kierunków myślowych. Były one często niczym wzburzone fale, które popychały myślenie wielu chrześcijan niczym małą łódkę z jednej skrajności w drugą: od marksizmu do liberalizmu, aż po libertynizm; od kolektywizmu po radykalny indywidualizm; od ateizmu do mglistego mistycyzmu religijnego; od agnostycyzmu do synkretyzmu itd. Każdego dnia powstają nowe sekty i urzeczywistnia się to, co mówi św. Paweł na temat «oszustwa ze strony ludzi i przebiegłości w sprowadzaniu na manowce fałszu» (Ef 4, 14). Wyznawanie jasno określonej wiary, zgodnie z Credo Kościoła, jest często określane jako fundamentalizm. Natomiast relatywizm, to znaczy poddawanie się «każdemu powiewowi nauki», jawi się jako jedyna postawa godna współczesnej epoki. Tworzy się swoista dyktatura relatywizmu, który niczego nie uznaje za ostateczne i jako jedyną miarę rzeczy pozostawia tylko własne ja i jego zachcianki" $"$.

Dyktatura relatywizmu, o której wspominał kard. Ratzinger, prowadzi do uznania za powszechną normę faktu, że nie ma żadnej obiektywnej prawdy, wszelkie wartości mają charakter zmienny, a jedynym wyznacznikiem postrzegania rzeczywistości jest moje własne ,ja”. Taką postawę określa się jako subiektywizm. Występuje on w różnych odmianach, np. jako subiektywizm ontyczny, poznawczy czy też etyczny. Zasadniczo polega on na tym, że tylko własne przekonania uznaje się za jedynie słuszne i prawdziwe, mające charakter dyrektywny i wyznaczające moralne granice postępowania ${ }^{19}$. Wówczas prawdą jest to, co dana jednostka uważa z prawdę, dobrem zaś to, co jest przez nią uznane za dobre. Ostatecznym zatem źródłem prawdy pozostaje indywidualne ,ja”. Takie przekonanie, które w jednostkowym ,ja" widzi jedyne kryterium prawdy i dobra, głosi się w imię wolności sumienia, prawa do posiadania własnych przekonań i kierowania się nimi przy dokonywaniu wyborów moralnych ${ }^{20}$. Ci, którzy takie poglądy głoszą, absolutyzują indywidualną wolność ludzką. W ich przekonaniu, gdyby istniały obiektywne wartości niezależne w swym istnieniu od ,ja”, wolność byłaby tylko pozorna. Pisał o tym Jan Paweł II w Encyklice Veritatis splendor, będącej swego

16 Jan Paweł II, Pamięć i tożsamość, Kraków 2005, s. 19.

17 Por. Katechizm Kościoła Katolickiego, Poznań 2002, s. 441.

18 J. Ratzinger, Ku ,dojrzałości” wiary w Chrystusa. 18 IV 2005 - Homilia kard. Josepha Ratzingera podczas Mszy św. „pro eligendo Romano Pontifice”, opoka.org.pl/bibliote$\mathrm{ka} / \mathrm{W} / \mathrm{WR} / \mathrm{inne} /$ ratzinger_proeligendo_18042005.html [dostęp: 28 IX 2020 r.].

19 Por. S. Gaworek, Utracony blask, dz. cyt., s. 163.

20 J. Ratzinger, Raport o stanie wiary, thum. Z. Oryszyn, Warszawa-Struga 1986, s. 77-78. 
rodzaju manifestem przeciwko relatywizmowi: „I tak, w niektórych nurtach myśli współczesnej do tego stopnia podkreśla się znaczenie wolności, że czyni się z niej absolut, który ma być źródłem wartości. [...] Sumieniu indywidualnemu przyznaje się prerogatywy najwyższej instancji osądu moralnego, która kategorycznie i nieomylnie decyduje o tym, co jest dobre, a co złe. Do tezy o obowiązku kierowania się własnym sumieniem niesłusznie dodano tezę, wedle której osąd moralny jest prawdziwy na mocy samego faktu, że pochodzi z sumienia. Wskutek tego zanikł jednak nieodzowny wymóg prawdy, ustępując miejsca kryterium szczerości, autentyczności, «zgody z samym sobą», co doprowadziło do skrajnie subiektywistycznej interpretacji osądu moralnego. [...] Wizja ta łączy się z etyką indywidualistyczną, według której każdy człowiek staje wobec własnej prawdy, różnej od prawdy innych. Posunięty do skrajnych konsekwencji, indywidualizm prowadzi do zaprzeczenia samej idei natury ludzkiej"21.

Konsekwencją panowania subiektywizmu we współczesnej kulturze jest radykalne przewartościowanie najbardziej fundamentalnych pojęć i zasad moralnych, takich jak uczciwość, prawdomówność, odpowiedzialność, czystość itp. Związane są one z wrodzoną wrażliwością moralną, dzięki której jest możliwe odróżnianie dobra od zła. Współcześnie w stosunku do tych podstawowych pojęć zwolennicy subiektywizmu przyjmują stanowisko kwestionujące ich obiektywność i uniwersalność. Ewangeliczne zapewnienie ,prawda was wyzwoli” (J 8, 32), zostaje zastąpione stwierdzeniem: „niewiara w jakąkolwiek obiektywną prawdę was wyzwoli”, ponieważ nie będzie wówczas żadnych obiektywnych norm ograniczających swobodę działania ${ }^{22}$. Tak rozumiany subiektywizm prowadzi do zaniku świadomości grzechu i utraty jakiegokolwiek zmysłu moralnego, a w konsekwencji do braku odpowiedzialności, amoralności i społecznego zobojętnienia吕. Wspomniany już prof. Roberto de Mattei opisuje fazy rozwoju ideologii relatywizmu w trzech etapach: „Pierwszym jest negacja istnienia wartości obiektywnych i uniwersalnych, czego konsekwencję stanowi zrównanie dobra i zła, grzechu i cnoty. Drugim - instytucjonalizacja dewiacji moralnych objawiających się w przemianie prywatnej niegodziwości w publiczną cnotę. Trzecim wreszcie - wprowadzenie ostracyzmu społecznego i prawnej karalności dobra. Do tego momentu właśnie doszliśmy. Żyjemy

21 Jan Paweł II, Veritatis splendor, Wrocław 1993, s. 51-52.

22 Por. S. Gaworek, Utracony blask, dz. cyt., s. 176-177.

23 Przykładem utraty poczucia zła moralnego jest chociażby głośno komentowany kazus z 22 lipca 2011 r. Anders Behring Breivik, 33-letni Norweg, z zimną krwią zamordowa1 na wyspie Utoya prawie 70 osób, a kilkaset ranił. Jest rzeczą znamienną, że morderca po dokonaniu krwawej masakry przyznał, iż zdaje on sobie sprawę z tego, że inni będą uważać jego czyn za potworny, lecz on sam ocenia go jako dobry i zasługujący na moralne usprawiedliwienie. Jak bardzo trzeba mieć zdeprawowane sumienie, by nie widzieć niczego złego w dokonaniu tak tragicznego w swych skutkach czynu! Oto właśnie widzialny owoc utraty poczucia grzechu. gazetaprawna.pl/artykuly/1491070,breivik-ponownie-wystapil-o-przedterminowe-warunkowe-zwolnienie-z-wiezienia.html [dostęp: 6 X 2020 r.]. 
w społeczeństwie hołdującym swoistemu anty-Dekalogowi, w którym dozwolone jest wszystko poza publicznym deklarowaniem wierności zasadom porządku naturalnego i chrześcijańskiego. Jest to zarazem ostatni moment, aby przeciwstawić się dyktaturze relatywizmu"24. Trudno nie przyznać racji prof. Mattei, w wielu bowiem krajach, zwłaszcza europejskich (także w Polsce), nastała trzecia faza opisanego wyżej procesu, co jest dowodem na to, że dyktatura relatywizmu jest realnym zagrożeniem i staje się powoli zjawiskiem powszechnym ${ }^{25}$.

Należy zatem stwierdzić, że relatywizacja prawdy zawsze nieuchronnie prowadzi do tego, że daje o sobie znać skrajny subiektywizm, dotyczący przede wszystkim kwalifikacji czynu moralnego człowieka. Indywidualnemu sumieniu przyznaje się prerogatywy najwyższej instancji osądu moralnego, która kategorycznie i nieomylnie decyduje o tym, co jest dobre, a co złe ${ }^{26}$. W tym sensie słowa Chrystusa „Poznacie prawdę, a prawda was wyzwoli” (J 8, 32), oraz „Każdy, kto popełnia grzech, jest niewolnikiem grzechu" (w. 34) stają się dla współczesnego człowieka coraz bardziej niezrozumiałe. Jeżeli bowiem nie istnieje żadna obiektywna prawda o dobru i złu moralnym, wówczas zanika świadomość i poczucie grzechu. Sumienie człowieka ulega znieczuleniu i w konsekwencji staje się niewrażliwe na wszelkie przejawy zła moralnego.

\section{Błędna koncepcja Kościoła}

Jak już to zostało powiedziane, współczesna utrata świadomości grzechu wiąże się z kryzysem wiary, ten zaś powoduje, że także spojrzenie na Kościół ulega zniekształceniu. Pytanie, jakie nasuwa się w tym miejscu, brzmi następująco: Jeżeli Bóg w mentalności współczesnego człowieka stał się wielkim nieobecnym, to czym w takim razie jest Kościół? Mierząc się z tą kwestią, kard. J. Ratzinger w książce Raport o stanie wiary pisał: „Alarm dotyczy przede wszystkim kryzysu koncepcji Kościoła, eklezjologii: «Tu ma swój początek większa część nieporozumień lub istotnych błędów i pułapek, w które wpadają tak teologia, jak i opinia publiczna Kościoła. Mam wrażenie, że wielu nie odrzuca Kościoła jawnie, z rozmysłem, ale odchodzi od niego po cichu, gubiąc po drodze autentyczny katolicki sens jego rzeczywistości. Wielu nie wierzy już więcej, że chodzi tu o rzeczywistość, której chciał sam Chrystus. Nawet niektórzy teologowie traktują Kościół jako budowlę wzniesioną przez człowieka, przez nas samych, a więc reorganizowaną wedle potrzeb chwili. [...] W wyłącznie socjologicznej - pozbawionej wizji nadprzyrodzonego misterium - koncepcji Kościoła, nawet chrystologia zatraca swoje odniesienie do Boskości. Ewangelia staje się tylko Jezusem-projektem, projektem społeczno-wyzwoleńczym. Projektem czysto historycznym, ograniczonym

24 R. de Mattei, Dyktatura relatywizmu, dz. cyt., s. 45.

25 Por. S. Gaworek, Utracony blask, dz. cyt., s. 13.

26 Por. Jan Paweł II, Veritatis splendor, dz. cyt., s. 52. 
wyłącznie do ziemskiej rzeczywistości, w swej istocie zaś ateistycznym»"27. Jak wynika z powyższego tekstu, zdaniem Ratzingera Kościół w oderwaniu od Boga, w oderwaniu od Chrystusa staje się rzeczywistością wyłącznie ludzką, gdyż jego geneza jest wyłącznie ludzka. Zostaje odarty wówczas z właściwej mu nadprzyrodzoności, co w konsekwencji prowadzi do utraty przez niego cechy autorytatywności, której gwarantem jest sam Bóg. „Wraz z zagubieniem prawdziwej koncepcji Kościoła zatraca się prawdziwy sens posłuszeństwa. Niektórzy nie zaliczają go już do cnót chrześcijańskich. Odrzuca się je jako spuściznę «przeszłości autorytarnej». Jeżeli uważa się, że Kościół jest nasz, że Kościół to tylko my, że jego struktura nie jest Chrystusowa, to przestaje się uznawać hierarchię kościelną za ustanowioną przez samego Chrystusa służbę ochrzczonym. W ten sposób odrzuca się ideę autorytetu uwierzytelnionego przez Boga, ideę władzy pochodzącej od Niego, która jest przecież inna niż władza struktur politycznych, ustanowiona przez konsensus większości członków danej organizacji”28.

Fałszywa koncepcja Kościoła pozbawia go wiarygodności i czyni organizacją, tak jak wiele innych stowarzyszeń świeckich, wyłącznie ludzką, a więc pozbawioną prerogatywy nadprzyrodzoności, która nadawała mu wyjątkową pozycję na tle innych instytucji. Tym samym gdy odrzuca się go jako urząd nauczycielski, do którego misji należy przekazywanie depozytu wiary i moralności ${ }^{29}$, traci on swoją autorytatywność. W efekcie nie może być dla współczesnego człowieka wyznacznikiem w dziedzinie moralności, nie może autorytatywnie wypowiadać się o ludzkich czynach jako dobrych bądź złych. Wyobrażenie, że jakiś ludzki czyn mógłby obrażać Boga, staje się dla wielu zupełnie nie do zaakceptowania ${ }^{30}$. Przyjęcie takiego sposobu myślenia prowadzi konsekwentnie do utraty świadomości grzechu, do zacierania granic pomiędzy dobrem a złem. Jeżeli to nie Kościół ma być wyznacznikiem porządku moralnego, jeżeli jego nauka w zakresie ludzkiego postępowania jest uważana za przestarzałą, nieaktualną, to oznacza to, że nie istnieje grzech, który jest

27 J. Ratzinger, Raport o stanie..., dz. cyt., s. 39-40.

28 J. Ratzinger, Raport o stanie..., dz. cyt., s. 42.

${ }^{29}$ „Ta nieomylność, w którą Boski Odkupiciel zechciał wyposażyć Kościół swój w określaniu nauki wiary lub obyczajów, ma taki zakres, jak i depozyt boskiego Objawienia, który ma być ze czcią przechowywany i wiernie wykładany. Nieomylnością tą z tytułu swego urzędu cieszy się Biskup Rzymski, Głowa Kolegium Biskupiego, gdy jako najwyższy pasterz i nauczyciel wszystkich wiernych Chrystusowych, który braci swych umacnia w wierze, ogłasza definitywnym aktem naukę dotyczącą wiary i obyczajów. Toteż orzeczenia jego słusznie zwane są nienaruszalnymi same z siebie, a nie na mocy zgody Kościoła, jako że ogłoszone zostały z pomocą Ducha Świętego przyrzeczoną mu w osobie św. Piotra i dlatego nie potrzebuje niczyjej aprobaty ani nie dopuszczają odwoływania się do niczyjego sądu”. Sobór Watykański II, Konstytucja dogmatyczna o Kościele „Lumen gentium”, w: Sobór Watykański II. Konstytucje, dekrety, deklaracje, Poznań 2002, s. 128.

30 J. Ratzinger, Nowa pieśń dla Pana, tłum. J. Zychowicz, Kraków 2005, s. 55. 
przecież świadomym i dobrowolnym przekroczeniem porządku moralnego ustanowionego przez Boga i ogłoszonego przez Kościół.

W świetle dotychczasowych analiz widać wyraźnie, że kryzys wiary i będąca jego konsekwencją zredukowana i zafałszowana wizja rzeczywistości Kościoła popychają współczesnego człowieka do przyjęcia skrajnie relatywistycznej wizji moralności. To z kolei pogłębia zanik świadomości grzechu i skutkuje coraz większą niewrażliwością ludzkiego sumienia.

\section{Przyczyny psychologiczne}

Zjawisko zaniku poczucia grzechu ma także swoje podłoże psychologiczne. Wynika ono z silnego dążenia współczesnego człowieka do kreowania pozytywnego wizerunku samego siebie. Ponieważ grzech obciąża winą tego, kto go popełnia, dlatego silne poczucie grzechu sprzeciwia się tak intensywnie promowanej w dzisiejszych czasach narracji samozachwytu. Świadomość tego, że niektóre czyny danej osoby są niezgodne z obiektywnymi normami postępowania, a więc że popełnia ona wówczas zło i że jest za nie odpowiedzialna, kłóci się z ową wizją samej siebie, dzięki której kreuje się dzisiaj swój pozytywny wizerunek jako osoby nieskazitelnej i niemal doskonałej. Do tego dochodzi również niepoprawnie rozumiana wolność jako możliwość czynienia bez żadnych ograniczeń tego, co subiektywnie uważa się za słuszne. Wówczas nauka o grzechu jawi się jako swoistego rodzaju hamulec dla tak rozumianej wolności. Jan Paweł II we wspomnianej już adhortacji o sakramencie pokuty i pojednania także zwrócił uwagę na czynnik psychologiczny odwodzący od poczucia grzechu: „Zanikanie poczucia grzechu we współczesnym społeczeństwie jest również wynikiem dwuznaczności, w którą się popada, przyjmując niektóre wyniki wiedzy ludzkiej. Tak więc na podstawie niektórych twierdzeń psychologii troska, by nie obciążać winą czy nie hamować wolności, prowadzi do nieuznawania w żadnym wypadku jakiegokolwiek uchybienia. Wskutek niewłaściwej ekstrapolacji kryteriów wiedzy socjologicznej dochodzi się - jak już zaznaczyłem - do zrzucenia na społeczeństwo wszelkich win, od których uwalnia się jednostkę. Podobnie pewien rodzaj antropologii kulturalnej, poprzez wyolbrzymianie skądinąd niezaprzeczalnych uwarunkowań i wpływów środowiskowych i historycznych oddziaływujących na człowieka, nazbyt ogranicza jego odpowiedzialność, nie uznając, że człowiek jest zdolny do wykonywania aktów prawdziwie ludzkich, a zatem nie uznaje możliwości popełnienia grzechu" ${ }^{\prime 1}$.

A zatem dobre samopoczucie staje się ważniejsze od kryterium prawdy. W efekcie dążenie do postrzegania siebie w utopijnych ramach doskonałości skutkuje wypieraniem poczucia grzechu z własnej świadomości. W imię niewłaściwie pojętego kreowania własnego wizerunku osłabia się wrażliwość swego sumienia na zło mo-

31 Jan Paweł II, Reconciliatio et paenitentia, art. cyt., s. 227. 
ralne ${ }^{32}$. Ostatecznie prowadzi to do ucieczki od prawdy o sobie samym i od odpowiedzialności za popełnione czyny.

Kolejną psychologiczną przyczyną zatracania świadomości grzechu jest tzw. utylitaryzm etyczny. Głównym postulatem owej teorii etyczno-filozoficznej jest dążenie do poszukiwania szczęścia w stopniu maksymalnym. Chociaż postulat sam w sobie wydaje się nie implikować negatywnych postaw, to jednak współcześnie niesie za sobą niemałe zagrożenie ${ }^{33}$. Obecnie bowiem szczęście jest postrzegane jako dążenie do intensyfikacji przyjemności i doznań. Takie pojmowanie szczęścia prowadzi zwykle do kontestowania obiektywnych norm etycznych. Jan Paweł II wskazał na to niepokojące zjawisko chociażby w liście skierowanym do rodzin: „Motywacją etycznego utylitaryzmu jest - jak wiadomo - intensywne poszukiwanie szczęścia w stopniu maksymalnym. Jednakże to «utylitarystyczne szczęście» bywa pojmowane tylko jako przyjemność, jako doraźne zaspokojenie, które «uszczęśliwia» poszczególne jednostki bez względu na obiektywne wymagania prawdziwego dobra. Cały ten program utylitaryzmu, związany z indywidualistycznie zaprogramowaną wolnością - wolnością bez odpowiedzialności - jest antytezą miłości, również jako wyrazu ludzkiej cywilizacji, jej całościowego i spójnego kształtu"34.

Jeżeli więc dążenie do przyjemności staje się celem samym w sobie, to wówczas wszelkie obiektywne normy ograniczające to dążenie są postrzegane jako źródło zagrożenia dla własnego pozornego szczęścia. Zgodnie z taką logiką myślenia np. miłość fizyczna jest ukazywana jako poszukiwanie samego siebie, własnego zadowolenia. Seksualność nie ma tutaj bynajmniej nic wspólnego z dawaniem siebie, lecz jest rozumiana jako dążenie do osobistej, hedonistycznej satysfakcji. W tej dziedzinie pojawia się dzisiaj wiele zasługujących na moralne potępienie czynów i postaw, takich jak np. nadużycia seksualne wobec nieletnich (zwłaszcza pedofilia), prostytucja i pornografia ${ }^{35}$. Te dysfunkcyjne zachowania, za którymi kryją się nierzadko głębokie zaburzenia osobowości, uderzają przede wszystkim w najsłabszych: kobiety i dzieci. Nigdzie indziej redukcja osoby do rzeczy nie jest tak bardzo widoczna jak w wymienionych wyżej rodzajach seksualnego wyzysku. Dominacja hedonistycznej wizji szczęścia prowadzi nawet do tego, że jej zwolennicy domagają

32 Przykładem takiego postępowania jest kontestowanie zobowiązania wierności małżeńskiej przez osoby żyjące w powtórnych związkach bądź też dyskredytowanie wartości celibatu pośród duchownych, którzy porzucili stan kapłański. Jest to podświadoma próba zdjęcia z siebie odpowiedzialności za popełnione czyny, pragnienie usprawiedliwienia popełnionego grzechu we własnych oczach.

33 „Pragnienie, by żyć lepiej, nie jest niczym złym, ale błędem jest styl życia, który wyżej stawia dążenie do tego, by mieć aniżeli być, i chce więcej mieć nie po to, aby bardziej być, lecz by doznać w życiu jak najwięcej przyjemności”. Jan Paweł II, Centesimus annus, Wrocław 1991, s. 75.

34 Jan Paweł II, Gratissimam sane, Poznań 1994, s. 49.

35 Por. S. Gaworek, Utracony blask, dz. cyt., s. 84. 
się legalizacji dewiacji seksualnych ${ }^{36}$ oraz zanegowania wartości zabezpieczających miłość małżeńską, takich jak wierność i nierozerwalność małżeńska. Na gruncie tak rozumianego szczęścia pojawiło się również pojęcie tzw. wolnej miłości, której głównym wyznacznikiem jest kierowanie się tzw. prawdziwym uczuciem. Za tak rozumianą miłością jako intensywnej emocji kryje się sugestia, aby zawsze iść za nią niezależnie od podjętych uprzednio zobowiązań. Taka postawa pozornie ma służyć miłości „wolnej”, chociaż w rzeczywistości czyni człowieka niewolnikiem tego, co św. Tomasz nazywa „passiones animae”37 - niewolnikiem ludzkich namiętności i instynktów. Iluzja „wolnej miłości” wykorzystuje ludzkie słabości, buduje pewną scenerię szlachetności za pomocą różnych środków uwodzenia i doraźnej aprobaty opinii publicznej. W ten sposób usiłuje ona zagłuszyć moralne wyrzuty prawego sumienia i stworzyć moralne alibi. Nie bierze jednak pod uwagę wszystkich konsekwencji, zwłaszcza gdy bolesną cenę oprócz małżonka płacą za nią dzieci, które zostają pozbawione własnego ojca lub matki ${ }^{38}$. Za tą hedonistyczną postawą kryje się w rzeczywistości pragnienie łatwego życia i szczęścia, pozbawionego obiektywnych wymogów prawdziwego dobra. Pociąga ona za sobą swoisty kult ciała, które staje się jedynie podmiotem dostarczania zmysłowych doznań i przeżyć stanowiących miarę niewłaściwie pojętej szczęśliwości. W konsekwencji wszystko to, co sprzeciwia się tak rozumianemu dążeniu do szczęścia, jest przez propagatorów utylitarystycznej i hedonistycznej wizji życia postrzeganie jako zagrożenie. Największym wrogiem staje się dla nich prawo moralne stawiające granicę opisanym wyżej nadużyciom. I dlatego dążą oni do wyparcia ze świadomości ludzi poczucia grzechu, aby „wyzwolić" ich od fałszywego, w ich mniemaniu, poczucia winny.

Widać więc, że czynniki psychologiczne mają znaczący wpływ na utratę świadomości grzechu. Zarówno dążenie do kreowania pozytywnego wizerunku samego siebie, jak i do łatwego i wygodnego życia powodują odrzucenie kryterium obiektywnej prawdy wyznaczającej porządek moralny. W obu opisanych wyżej przypadkach obiektywna prawda o dobru i złu moralnym jest widziana jako zagrożenie dla autorealizacji. Poczucie grzechu staje się przeszkodą do spełnienia różnych niemoralnych dążeń i pragnień, stąd presja, zwłaszcza ze strony zwolenników nowych ideologii, takich chociażby ruch LGBT, by je całkowicie wyprzeć ze świadomości moralnej człowieka. Natomiast wszystko, co przypomina o istnieniu zła i grzechu, a przede wszystkim Kościół katolicki, który samym swoim nauczaniem budzi wyrzuty sumienia, należy zanegować i odrzucić jako czynniki hamujące samorealizację współczesnego człowieka.

36 Przykładem są postulaty dążące do legalizacji pedofilii jako jednej z „,nowych orientacji seksualnych”. Zob. pch24.pl/legalizacja-pedofilii--ostatnie-stadium-moralnego-upadku--opinia-,65453,i.html [dostęp 29 IX 2020 r.].

37 Tomasz z Akwinu, Suma teologiczna, t. 10, Uczucia, London 1967, s. 16.

38 Jan Paweł II, Gratissimam sane, dz. cyt., s. 49. 


\section{Odpowiedź św. Tomasza na zanik świadomości grzechu}

Po wskazaniu i omówieniu zasadniczych przyczyn utraty świadomości grzechu przez ludzi żyjących w obecnych czasach, należy teraz, opierając się na myśli św. Tomasza z Akwinu, podjąć próbę znalezienia dróg prowadzących do odwrócenia tego pogłębiającego się kryzysu. Warto przyjrzeć się najpierw podstawowym założeniom myślowym Doktora Anielskiego i zasadniczym wnioskom z nich wynikającym.

\section{Powrót do realizmu i obiektywizmu poznawczego}

Gdy przyjrzeć się bliżej opisanym wyżej przyczynom utraty świadomości grzechu, bez trudu da się zauważyć, że ich wspólnym mianownikiem jest odrzucenie kryterium prawdy obiektywnej. Zakwestionowanie możliwości poznania prawdy obiektywnej i uniwersalnej prowadzi w konsekwencji do odrzucenia także moralności opartej na koncepcji prawa naturalnego, a więc na istnieniu wartości obiektywnych. W ten sposób człowiek sam dla siebie staje się wyznacznikiem moralności, decydując o tym, co jest dobre, a co złe. Indywidualnemu sumieniu przyznaje się wówczas przywilej nieomylnego osądu moralnego. To jednostka decyduje o tym, co jest dla niej dobrem, a co złem. Takie jednak postrzeganie moralności prowadzi do dominacji postaw skrajnie subiektywistycznych. W efekcie, zwłaszcza w odniesieniu do stanowienia prawa, niemożliwe staje się odwołanie do jakichkolwiek obiektywnych, powszechnie obowiązujących norm etycznych, gdyż wszystko staje się względne, zależne od interpretacji indywidualnego podmiotu. W starożytności prekursorami takiego subiektywistycznego podejścia byli sofiści, a w szczególności Protagoras z Abdery, autor sentencji „,człowiek jest miarą wszystkich rzeczy”, która stała się swoistą magna charta subiektywizmu ${ }^{39}$. Przyczyną dominacji tego typu subiektywistycznego postrzegania świata w czasach współczesnych jest głównie kryzys myślenia w duchu realistycznego nurtu filozofii klasycznej, poszukującego ostatecznego wyjaśnienia rzeczywistości. Kryzys ten rozpoczął się w okresie odrodzenia, spotęgował się zaś w czasach nowożytnych, zwłaszcza po opublikowaniu dzieł Kartezjusza. To właśnie ten myśliciel twierdził, że fundamentu prawdziwej nauki należy szukać nie w świecie zewnętrznym, lecz w człowieku, nie w przedmiocie, lecz w podmiocie, nie w materii, lecz w świadomym duchu. A więc to nie rzeczywistość pozapodmiotowa ma być punktem wyjścia, lecz sam podmiot i jego myśl: „cogito ergo sum”. W tym kartezjańskim odrzuceniu poszukiwania prawdy w świecie obiektywnym, pozapodmiotowym i skierowaniu uwagi na indywidualne „ja”, na to, co w sposób wyraźny jawi się w jego wnętrzu, należy dopatrywać się źródła współczesnych subiektywistycznych horyzontów myślenia.

39 Por. S. Gaworek, Utracony blask, dz. cyt., s. 169. 
Św. Tomasz z Akwinu odrzucał stanowczo stanowisko subiektywistyczne. Stał on na stanowisku realizmu i obiektywizmu poznawczego. Jego zdaniem w punkcie wyjścia wszelkiego poznania znajdują się rzeczy jednostkowe, istniejące realnie poza podmiotem poznającym, dostępne poznawczo człowiekowi poprzez doświadczenie zmysłowe. Innymi słowy, Akwinata uważa, że prawda o rzeczywistości znajduje się poza podmiotem poznającym. Człowiek prawdy nie tworzy, lecz ją odkrywa, poznając realnie istniejącą rzeczywistość. Zdecydowanie zatem św. Tomasz odrzuca zarówno relatywizm, jak i subiektywizm poznawczy, opowiadając się za arystotelesowską zasadą, wedle której całe ludzkie poznanie jest pochodzenia empirycznego: „nihil est in intellectu, quod prius non fuerit in sensu”"40. Dzięki poznaniu zmysłowemu eksplikowanemu później w poznaniu umysłowym rzeczywistość odsłania się człowiekowi w konkretnych jednostkowych istnieniach, które składają się na jej różnorodność i ontyczne bogactwo ${ }^{41}$. Człowiek w swoim najbardziej podstawowym doświadczeniu egzystencjalnym uświadamia sobie fakt istnienia poszczególnych bytów, a następnie poprzez kolejne akty poznania nawiązuje coraz głębszy kontakt z światem rzeczywistym. W ten sposób świat bytów realnych stopniowo otwiera się przed człowiekiem, który pragnie poznawać je coraz lepiej, aż do zidentyfikowania tych czynników, które tłumaczą ich istnienie i naturę w sposób ostateczny. W tym realistycznym poznaniu najważniejszy jest bezpośredni kontakt z rzeczywistością, z którego później wypływają sądy afirmujące istnienie bytów realnych ${ }^{42}$. Tylko takie realistyczne podejście gwarantuje możliwość poznawania i dogłębnego wyjaśniania świata. Dochodzi ono do głosu na gruncie takiego poznania metafizycznego, które nie zatrzymuje się na samym poznaniu zmysłowym, lecz prowadzi do metodycznego poszukiwania przyczyn tego, co istnieje. W poszukiwaniu tym metafizyka realistyczna posługuje się głównie rozumowaniem redukcyjnym. W tego typu rozumowaniu dla znanego prawdziwego następstwa szuka się uzasadniającej go racji. Rozumowanie zatem przechodzi tu od skutku do przyczyny. Taki przebieg procesu myślowego zakłada nieustanny i bezpośredni kontakt z rzeczywistością, a więc $\mathrm{z}$ tym, co jawi się poznaniu jako realnie istniejące, ponieważ zgodnie z klasyczną definicją prawdy tylko obiektywna rzeczywistość może ostatecznie weryfikować prawdziwość sądów ludzkich o niej samej, a więc o tym, co istnieje niezależnie od naszego poznania, a co się nie thumaczy samo przez się, lecz domaga się wskazania ostatecznych racji swego istnienia i swej tożsamości ${ }^{43}$.

40 „Nie ma w intelekcie niczego, czego przedtem nie było w zmyśle”. I dalej: „W Bogu jednak nie można przyjmować poznania zmysłowego, gdyż jest ono materialne”. Tomasz z Akwinu, Kwestie dyskutowane o prawdzie, t. 1, tłum. A. Aduszkiewicz, L. Kuczyński, J. Ruszczyński, Kęty 1998, s. 82.

${ }^{41}$ „Każdy byt o tyle jest poznawalny, o ile jest w istności (in actu)”. Tomasz z Akwinu, Suma teologiczna, t. 1, O Bogu, London 1975, s. 196.

42 É. Gilson, Byt i istota, tłum. B. Eska, J. Nowak, Warszawa 1962, s. 218-219.

43 „Otóż nie jest rzeczą możliwą, by istnienie danej rzeczy było skutkiem działania jej formy lub istoty; forma czy też istota nie mogą być przyczyną sprawczą istnienia, wówczas 
Widać zatem, że w świetle doktryny św. Tomasza odpowiedzią na współcześnie dominującą mentalność subiektywistyczną winien być powrót do realizmu i obiektywizmu poznawczego, a więc do takiej filozofii, dla której punktem wyjścia jest realnie istniejąca rzeczywistość pozapodmiotowa. Tylko w ten sposób człowiek jest W stanie otworzyć się na poszukiwanie prawdy gwarantującej porządek moralny w świecie.

\section{Bóg jako źródło prawa moralnego}

Na początku niniejszego artykułu stwierdzono, że główną przyczyną zatracania poczucia grzechu jest kryzys wiary. Bardzo często przejawia się on w postaci agnostycyzmu religijnego, a więc pewnego przekonania o niemożności racjonalnego udowodnienia faktu istnienia Boga. Agnostycyzm ów jest w gruncie rzeczy przejawem kryzysu rozumu mającego swoje źródło w opisanym wyżej odejściu od realistycznego myślenia, którego punktem wyjścia jest istniejąca rzeczywistość.

Św. Tomasz jest zupełnie innego zdania niż zwolennicy agnostycyzmu. W Sumie teologicznej twierdzi on, że fakt istnienia Boga jest oczywistością samą w sobie, lecz nie jest czymś oczywistym dla czytelnika, dlatego istnienia Boga należy dowieśćc ${ }^{4}$. Przedstawia on pięć dowodów zwanych drogami, które każdego, kto podejmuje uczciwą wędrówkę intelektualną, winny doprowadzić do stwierdzenia, że Bóg istnieje. Drogi te mają charakter aposterioryczny: wychodzą od bytów przygodnych, poznawalnych zmysłami i na drodze myślenia redukcyjnego prowadzą do uznania faktu istnienia przyczyny pierwszej - Boga. Natura bytów przygodnych, ich ontyczna niesamowystarczalność wskazuje pośrednio na istnienie Boga. Dzięki naturalnemu światłu rozumu człowiek może osiągnąć poznanie istnienia Boga jako owoc refleksji nad stworzeniami i ich stosunkiem do Stwórcy. To Jego istnienie nie jest czymś otrzymanym, zależnym od istnienia innych bytów, lecz jest czymś, co istnieje samo przez się (ipsum esse subsistens) ${ }^{45}$. „Bóg nie tylko jest swoją istotą [...], ale co więcej, Bóg jest samym istnieniem"46. Św. Tomasz stwierdza ponadto, że rozum

bowiem rzecz byłaby sama dla siebie przyczyną i sama siebie powoływałaby do istnienia, a to jest niemożliwe. Każda więc rzecz, której istnienie nie utożsamia się z istotą, otrzymuje to istnienie od innej rzeczy. Wszystko, co zawdzięcza swe istnienie czemu innemu, sprowadza się w końcu jako do swej przyczyny do tego, co istnieje samo przez się". Tomasz z Akwinu, Byt $i$ istota, thum. W. Sieńko, Warszawa 1978, s. 13.

44 „Dico ergo quo haec propositio, Deus est, quantum in se est, per se nota est: quia praedicatum est idem cum subiecto: Deus enim est suum esse, ut infra patebit (q. 3, a. 4). Sed quia nos non scimus de Deo quid est, non est nobis per se nota: sed indiget demonstrari per ea quae sunt magis nota quoad nos, et minus nota quoad naturam, scilicet per effectus". Tomasz z Akwinu, Suma teologiczna, t. 1, dz. cyt., s. 78.

45 S. Swieżawski, Dzieje europejskiej filozofii klasycznej, Warszawa-Wrocław 2000, s. 648.

46 „Dicendum quo Deus non solum est sua essentia, [...] sed etami suum esse”. Tomasz z Akwinu, Suma teologiczna, t. 1, dz. cyt., s. 93. 
ludzki jest w stanie wznieść się nie tylko do poznania tego, że Bóg jest, lecz także do tego, jaki jest. Jest w stanie poznać niektóre przymioty Jego natury, np. że jest On bytem najdoskonalszym, niezmiennym, że jest pierwszą przyczyną, że jest nieskończony, wieczny i wszechwiedzący itd. Zdaniem Akwinaty poznanie istnienia Boga i Jego natury jest koniecznym zwieńczeniem i ukoronowaniem metafizycznego poznania rzeczywistości ${ }^{47}$. Według Doktora Anielskiego człowiek dzięki wysiłkowi intelektualnemu jest w stanie od poznania rzeczy stworzonych, poznawalnych zmysłami, dojść do uznania faktu istnienia Boga. W ten sposób św. Tomasz wykazuje, że agnostycyzm negujący możliwość poznania Boga jest w dużej mierze kryzysem rozumu, a drogą do jego przezwyciężenia jest powrót do realizmu poznawczego.

Św. Tomasz prowadzi również refleksję nad stosunkiem stworzeń do Stwórcy, nad tym, jak istnienie Boga uobecnia się w świecie bytów stworzonych. Zauważa on, że Bóg, stwarzając, a więc udzielając swojego istnienia bytom przygodnym, nadał im pewną celowość i porządek istnienia, co Akwinata nazywa prawem wiecznym. W każdym istniejącym bycie odzwierciedla się ów porządek nadany przez Boga stworzonemu przez siebie światu. Ostatecznym celem owego zamysłu jest poznanie Boga jako bytu absolutnego, który jest uzasadnieniem dla wszelkiego istnienia i działania ${ }^{48}$.

47 „Celem każdej substancji obdarzonej umysłem, nawet najniższej, jest umysłowe poznanie Boga. Wykazaliśmy bowiem powyżej, że ostatecznym celem, do którego dążą wszystkie byty, jest Bóg. Intelekt ludzki zaś, chociaż jest najniższy w porządku substancji umysłowych, jest jednak wyższy od wszystkich, które nie posiadają intelektu. Skoro więc szlachetniejsza substancja nie może mieć mniej szlachetnego celu, Bóg będzie celem także dla intelektu ludzkiego. Każdy zaś byt poznający umysłowo osiąga swój cel ostateczny przez to, że go poznaje umysłowo, jak wykazaliśmy. A zatem przez poznanie umysłowe intelekt ludzki dochodzi do Boga jako do celu. A zatem poznanie Boga w sposób umysłowy (cognoscere Deum intelligendo) jest celem ostatecznym każdej substancji obdarzonej umysłem". Tomasz z Akwinu, Summa contra gentiles. Prawda wiary chrześcijańskiej $w$ dyskusji z poganami, innowiercami i błądzacymi, t. 2, tłum. Z. Włodek, W. Zega, Poznań 2007, s. 78.

48 „Jak w każdym twórcy istnieje wpierw pomysł tego, co on zamierza uskutecznić, tak również w każdym zarządzającym musi istnieć wpierw pomysł porządku tego wszystkiego, co mają czynić wszyscy podlegający jego rządom. A jak pomysł rzeczy, których twórca chce dokonać, zwie się sztuką lub wzorcem tychże rzeczy, tak również pomysł znajdujący się w umyśle zarządzającego ustanawiający porządek w czynnościach rzeczy, które mu podlegają, ma istotne cechy prawa [...]. Otóż Bóg jest stworzycielem wszystkich rzeczy przez swoją mądrość. Ma się On przeto do tych rzeczy tak, jak się ma każdy twórca do rzeczy przez siebie dokonanych. [...] Jest także rządcą wszystkich czynności i poruszeń, jakie wykonują poszczególne stworzenia. [...] Stąd też jak pomysł Bożej mądrości, poprzez który wszystko zostało stworzone, ma istotne znamię sztuki, prawzoru lub idei, tak również pomysł Bożej mądrości poruszającej wszystko ku właściwemu celowi, ma istotne znamię prawa. W myśl tego prawo wieczne jest niczym innym jak pomysłem Bożej mądrości, o ile ona nadaje kierunek wszystkim czynnościom i poruszeniom”. Tomasz z Akwinu, Suma teologiczna, t. 13, dz. cyt., s. 38 . 
Łatwo zatem dojść do wniosku, że prawo wieczne jest niezmiennym porządkiem istnienia ustanowionym przez Boga. Zdaniem Akwinaty każdy byt mający zdolność używania rozumu jest w stanie odczytać to prawo i respektować jego nor$\mathrm{my}^{49}$. Uważa on, że każde prawo stanowione winno być zapodmiotowane w prawie wiecznym: „Ponieważ prawo wieczne jest istniejącym w umyśle najwyższego rządzącego pomysłem rządzenia, dlatego wszystkie pomysły rządzenia, które znajdują się w niższych rządzących, muszą pochodzić od prawa wiecznego. Te zaś pomysły niższych rządzących są prawami, a chodzi o wszelkie inne prawa, poza prawem wiecznym. Stąd też wszystkie prawa o tyle pochodzą od prawa wiecznego, o ile pochodzą z rozumu należycie ustawionego. $Z$ tego to powodu Augustyn wyraził się: «W prawie doczesnym nie ma niczego sprawiedliwego i legalnego, czego by ludzie nie wywiedli od prawa wiecznego»" $"$.

Jeżeli więc prawo wieczne jest początkiem wszelkiego innego prawa, oznacza to, że także prawo moralne, wskazujące obiektywną normę postępowania, jest w nim zapodmiotowane ${ }^{51}$. Dla św. Tomasza to Bóg - jako Twórca prawa wiecznego - jest ostatecznie także źródłem prawa moralnego, nie zaś indywidualny podmiot, jak twierdzą zwolennicy subiektywizmu filozoficznego.

\section{Prawo naturalne jako antidotum na współczesny relatywizm}

Jak to już pokazano, św. Tomasz stoi na gruncie realistycznej wizji świata. Według niego człowiek nie jest twórcą rzeczywistości, ponieważ jest ona wcześniejsza niż jego poznanie i jego indywidualne istnienie. Uważa on, że jako byty rozumne ludzie są zdolni do tego, by kierować zarówno swoim poznawaniem rzeczywistości, jak i swoim działaniem, które wywiera na nią różnorodny wpływ. Zdolność postrzegania rzeczywistości taką, jaka jest, oraz zdolność do racjonalnego rozumowania

49 „W dwojaki sposób dana rzecz może być poznana: albo w samej sobie, albo w swoim skutku, w którym znajduje się jakieś jej podobieństwo, tak jak poznaje się słońce po jego promieniowaniu, chociaż nie widzi się samej jego substancji. [...] Natomiast wszelkie rozumne stworzenie może je poznać po jego większym lub mniejszym promieniowaniu, tj. udzielaniu się. Wszelkie bowiem poznanie prawdy jest jakimś promieniowaniem i udzielaniem się prawa wiecznego, które według Augustyna jest prawdą niezmienną. Wszyscy zaś w jakiś sposób poznają prawdę; przynajmniej co do pierwszych bardzo ogólnych zasad prawa naturalnego. Gdy chodzi o inne prawdy, to jedni mają większy udział w poznawaniu prawdy, a inni mniejszy. Zależnie też od tego więcej lub mniej poznają prawo wieczne”. Tomasz z Akwinu, Suma teologiczna, t. 13, dz. cyt., s. 40.

Tomasz z Akwinu, Suma teologiczna, t. 13, dz. cyt., s. 42.

51 „Jak przeto człowiek, wydając stanowcze zlecenie, wraża człowiekowi sobie poddanemu jakąś wewnętrzną zasadę postępowania, tak również i Bóg wraża całej naturze zasady właściwego jej postępowania. I w ten sposób mówi się o Bogu, że On nakazuje całej naturze, stosownie do słów psalmisty: Nadał jej prawo, które nie przeminie. Z tego też powodu podlegają prawu wiecznemu wszystkie ruchy i czynności całej natury”. Tomasz z Akwinu, Suma teologiczna, t. 13, dz. cyt., s. 47. 
staje się drogą, która prowadzi do przekonania o istnieniu Boga jako Stwórcy wszelkich istniejących bytów. Poznanie to prowadzi z kolei do odkrycia pewnego porządku wpisanego w obiektywnie istniejącą rzeczywistość, który św. Tomasz nazywa prawem wiecznym. Człowiek jako stworzenie rozumne został przez Stwórcę uzdolniony do uczestniczenia w prawie wiecznym. Innymi słowy, człowiek ma zdolność rozpoznania prawa naturalnego oraz jest zdolny do postępowania zgodnie z jego normami. Prawo naturalne bowiem - tak jak je definiuje św. Tomasz - to „udział prawa wiecznego w stworzeniu rozumnym" "52. Do tego poglądu Doktora Anielskiego nawiązuje chociażby poniższy tekst zawarty w Katechizmie Kościoła Katolickiego: „Człowiek uczestniczy w mądrości i dobroci Stwórcy, który przyznaje mu panowanie nad jego czynami i zdolność kierowania sobą ze względu na prawdę i dobro. Prawo naturalne wyraża pierwotny zmysł moralny, który pozwala człowiekowi rozpoznać rozumem, czym jest dobro i zło, prawda i kłamstwo"53. Innymi słowy, prawo naturalne, jako uczestniczenie w mądrości Boga, pozwala człowiekowi odczytać, co jest moralnym dobrem, a co złem, mimo że nie jest on w stanie poznać go w stopniu absolutnym ${ }^{54}$.

Powyższe odczytanie prawa naturalnego św. Tomasz wyprowadza z zasady działania ukierunkowanego na dobro: „Jak zaś byt jest tym, co jako istotnie pierwsze rozum pojmuje, tak dobro jest tym, co jako pierwsze pojmuje rozum praktyczny, który jest nastawiony na działanie. każdy bowiem działający działa dla celu, który ma znamiona dobra. I dlatego pierwsza zasada, jaką kieruje się rozum praktyczny, opiera się na pojęciu dobra. Brzmi ona: dobrem jest to, czego wszystko pożąda i ku czemu dąży. Zatem pierwsze przykazanie prawa jest takie: dobro należy czynić i dążyć doń, a zła należy unikać. Na tym opierają się wszystkie inne przykazania prawa natury: tak mianowicie, żeby do przykazań prawa naturalnego należały te wszystkie inne nakazy czynienia i unikania, które rozum praktyczny w naturalny sposób uznaje za dobre dla człowieka. A ponieważ dobro jest celem, a zło jest tego przeciwieństwem, dlatego wszystko to, ku czemu człowiek ma naturalną skłonność, rozum w naturalny sposób pojmuje jako dobro i w następstwie uważa, że należy czynnie ku niemu dążyć, a przeciwieństwo tego uznaje za zło i każe go unikać"55.

Tak więc człowiek podejmuje działanie ze względu na cel, który jawi mu się jako dobro. Nawet gdy czyni on obiektywne zło, czyni je dlatego, że rozpoznał w nim jakieś dobro. W tym sensie prawo naturalne jest wyrazem ogólnej zasady,

52 Tomasz z Akwinu, Suma teologiczna, t. 13, dz. cyt., s. 21.

53 Katechizm Kościoła Katolickiego, dz. cyt., s. 461.

54, ,...] Nikt z żyjących nie może poznać prawa wiecznego takim, jakim ono jest w samym sobie. W ten sposób mogą je poznać tylko święci w niebie, którzy widzą Boga w Jego istocie. Natomiast wszelkie rozumne stworzenie może je poznać po jego większym lub mniejszym promieniowaniu, tj. udzielaniu się. Wszelkie bowiem poznanie prawdy jest jakimś promieniowaniem i udzielaniem się prawa wiecznego, które według Augustyna jest prawdą niezmienną". Tomasz z Akwinu, Suma teologiczna, t. 13, dz. cyt., s. 40.

55 Tomasz z Akwinu, Suma teologiczna, t. 13, dz. cyt., s. 55. 
że dobro należy czynić, a zła unikać. Człowiek za pomocą światła rozumu, który umożliwia mu najbardziej całościowe i dogłębne poznanie rzeczywistości, rozpoznaje konkretną treść prawa naturalnego ${ }^{56}$. W szczególny sposób rozpoznanie to dokonuje się w sądzie sumienia. Jednakże prawda prawa naturalnego będzie dostępna człowiekowi wówczas, gdy odkryje, kim naprawdę jest, że jest realnie kimś więcej niż tylko częścią wspólnoty. Takie personalistyczne spojrzenie na istotę ludzką jest gwarantem właściwego odczytania prawdy zawartej w prawie naturalnym ${ }^{57}$.

Widać zatem wyraźnie, że św. Tomaszowi obcy jest pesymizm poznawczy. Jednocześnie jednak zdaje on sobie sprawę z niedoskonałości ludzkiego rozumu, który poznawanej rzeczywistości nie jest w stanie poznać adekwatnie i wobec tego musi stale podejmować wysiłek, by poznawać ją coraz lepiej i głębiej. Innymi słowy, nigdy nie powinien on zamykać się poznawczo w swoich utartych pojęciach na temat dobra i zła, jest to bowiem temat, który wymaga stałego intelektualnego namysłu ${ }^{58}$. O zasadniczej zdolności wszystkich ludzi do rozpoznawania prawa naturalnego oraz o tym, że zdolność ta nieraz ulega w nich zmąceniu, mówi św. Tomasz na początku swojego komentarza do Dekalogu w Wyktadzie pacierza: „Prawo natury jest niczym innym jak światłem w rozumu, wszczepionym nam przez Boga, dzięki któremu wiemy, co należy czynić i czego unikać. To światło i to prawo dał nam Pan Bóg w chwili stworzenia [...]. Każdy na przykład wie, że jeśli nie chce, by jemu coś czyniono, to sam drugiemu nie powinien tego czynić" ${ }^{59}$. Nikt zatem nigdy nie jest całkowicie odcięty od możliwości obiektywnego rozpoznawania dobra i zła.

Św. Tomasz zatem uważa, że normy prawa naturalnego są niezmienne i obowiązujące wszystkich ludzi, ponieważ natura ludzka pozostaje zawsze taka sama ${ }^{60}$. Co więcej, człowiek na mocy własnego wysiłku intelektualnego jest w stanie owe odwieczne prawa odczytać. Powrót do tej nauki św. Tomasza odwołującej się do koncepcji niezmiennego prawa natury może być odpowiedzią na współczesne nurty relatywistyczne, podważające możliwość odczytywania prawdy obiektywnej.

\section{Zakończenie}

Współczesna utrata świadomości grzechu ma swe główne źródło w ateistycznej wizji świata będącej przejawem kryzysu wiary, z jakim od pewnego czasu boryka się cywilizacja zachodnia. Odrzucenie faktu istnienia Boga pociąga za sobą konsekwen-

56 „Prasumienie zwie się prawem naszej myśli, gdyż jest sprawnością, która w swoim przedmiocie obejmuje przykazania prawa naturalnego; a te są pierwszymi zasadami ludzkiego postępowania". Tomasz z Akwinu, Suma teologiczna, t. 13, dz. cyt., s. 52-53.

57 J. Salij, Prawo naturalne i prawa stanowione w ujęciu św. Tomasza z Akwinu, „Łódzkie Studia Teologiczne" 16 (2007), nr 2, s. 105.

58 J. Salij, Prawo naturalne..., art. cyt., s. 106.

59 Tomasz z Akwinu, Wykład pacierza, tłum. W. Giertych, K. Suszyło, M. Starowieyski, Poznań 1987, s. 101.

${ }^{60}$ R. de Mattei, Dyktatura relatywizmu, dz. cyt., s. 65. 
cje w postaci relatywistycznego postrzegania rzeczywistości, błędnej koncepcji Kościoła czy też dążenia do kreowania własnego wizerunku za cenę odstąpienia od obiektywnej prawdy o swoich czynach. Wszystkie te czynniki współprzyczyniają się do współczesnej utraty świadomości grzechu. Doktryna św. Tomasza może stanowić jednak antidotum na chorobę duszy współczesnego człowieka, jaką jest bez wątpienia zanik świadomości grzechu. Droga prowadząca do odwrócenia nasilającego się kryzysu wiary i upadku moralności winna rozpocząć się od powrotu do realizmu i obiektywizmu poznawczego. Punktem wyjścia do poznania i działania winna być zawsze realnie istniejąca rzeczywistość, a nie subiektywistyczne spojrzenie jednostki. Tylko w ten sposób człowiek jest w stanie otworzyć się na poszukiwanie prawdy będącej gwarantem porządku moralnego w świecie. Próba przezwyciężenia kryzysu związanego z utratą poczucia grzechu winna oznaczać również konieczność powrotu to teistycznej wizji świata, w której Bóg stanowi punkt odniesienia dla całej rzeczywistości, zarówno jako jej pierwsza przyczyna, jak i jej ostateczny cel. Taki powrót do teistycznej wizji świata nie jest możliwy bez powrotu do metafizyki realistycznej. Albowiem kryzys wiary jest przede wszystkim kryzysem rozumu niezdolnego do koherentnego myślenia i wyciągania metafizycznych wniosków ukazujących obiektywny stan rzeczy. Ostatecznie powrót do realizmu i obiektywizmu poznawczego oraz do teistycznej wizji świata powinien skutkować powrotem do respektowania norm prawa naturalnego, z których człowiek jest w stanie wyprowadzić szczegółowe wnioski o dobru i złu moralnym własnego postępowania.

\section{Bibliografia}

\section{Źródla drukowane}

Jan Paweł II, Centesimus annus, Wrocław 1991.

Jan Paweł II, Gratissimam sane, Poznań 1994.

Jan Paweł II, Homilia w czasie Mszy św. beatyfikacyjnej Anieli Salawy, odprawionej na Rynku Gtównym (Kraków, 13 sierpnia 1991), opoka.org.pl/biblioteka/W/WP/ jan_pawel_ii/homilie/50krakow_13081991.html [dostęp: 28 IX 2020 r.].

Jan Paweł II, Reconciliatio et paenitentia, w: Adhortacje Jana Pawła II, t. 1, Kraków 1996.

Jan Paweł II, Veritatis splendor, Wrocław 1993.

Katechizm Kościoła Katolickiego, Poznań 2002.

Pius XII, Summi pontificatus, Warszawa 1998.

Ratzinger J., Ku ,dojrzatości” wiary w Chrystusa. 18 IV 2005 - Homilia kard. Josepha Ratzingera podczas Mszy św. ,pro eligendo Romano Pontifice”, opoka.org. $\mathrm{pl} /$ biblioteka/W/WR/inne/ratzinger_proeligendo_18042005.html [dostęp: 28 IX 2020 r.]. 
Sobór Watykański II, Konstytucja dogmatyczna o Kościele „Lumen gentium”, w: Sobór Watykański II. Konstytucje, dekrety, deklaracje, Poznań 2002, s. 104-166.

Tomasz z Akwinu, Byt i istota, tłum. W. Sieńko, Warszawa 1978.

Tomasz z Akwinu, Kwestie dyskutowane o prawdzie, t. 1, thum. A. Aduszkiewicz, L. Kuczyński, J. Ruszczyński, Kęty 1998.

Tomasz z Akwinu, Suma teologiczna, thum. P. Bełch, London 1986.

Tomasz z Akwinu, Summa contra gentiles. Prawda wiary chrześcijańskiej w dyskusji z poganami, innowiercami i bładzacymi, t. 1, tłum. Z. Włodek, W. Zega, Poznań 2003; t. 2, tłum. Z. Włodek, W. Zega, Poznań 2007.

Tomasz z Akwinu, Summa theologiae, San Paolo 1988.

Tomasz z Akwinu, Wykład pacierza, tłum. W. Giertych, K. Suszyło, M. Starowieyski, Poznań 2005.

\section{Opracowania}

Barber B., Skonsumowani, thum. H. Jankowska, Warszawa 2009.

Fromm E., Ucieczka od wolności, thum. O. i A. Ziemilscy, Warszawa 2008.

Gaworek. S., Utracony blask, Warszawa 2011.

Gilson É., Byt i istota, thum. B. Eska, J. Nowak, Warszawa 1962.

Heath R., Ukryta moc reklamy. Co tak naprawdę wptywa na wybór marki?, thum. A. Nowak, Gdańsk 2006.

Jan Paweł II, Pamięć i tożsamość, Kraków 2005.

Mattei R. de, Dyktatura relatywizmu, thum. P. Toboła-Pertkiewicz, E. Turlińska, Warszawa 2009.

Ratzinger J., Bóg $i$ świat, thum. G. Sowiński, Karków 2005.

Ratzinger J., Nowa pieśń dla Pana, thum. J. Zychowicz, Kraków 2005.

Ratzinger. J, Raport o stanie wiary, thum. Z. Oryszyn, Warszawa-Struga, 1986.

Salij J., Prawo naturalne i prawa stanowione w ujęciu św. Tomasza z Akwinu, „Łódzkie Studia Teologiczne” 26 (2007), nr 2, s. 103-110.

Swieżawski S., Dzieje europejskiej filozofii klasycznej, Warszawa-Wrocław 2000.

\section{Streszczenie}

Współcześnie, zwłaszcza w Europie, można zaobserwować postępującą fragmentaryzację społeczną i pogłębiającą się w szybkim tempie sekularyzację. W efekcie źródła moralności, takie jak rodzina, szkoła i Kościół, zaczęły stopniowo tracić właściwe im autorytatywne znaczenie. To z kolei prowadzi do postaw skrajnie subiektywistycznych. Dlatego kolejnym następstwem wymienionych wyżej procesów jest utrata świadomości grzechu. Źródłem znieczulenia moralnego jest pogłębiający się 
kryzys wiary, dominowanie postaw subiektywistycznych, niewłaściwa koncepcja Kościoła. Współczesny człowiek przestaje poszukiwać niezmiennych norm moralnych, które kształtowały społeczeństwa europejskie przez stulecia, ponieważ sam dla siebie staje się ich wyznacznikiem.

Wciąż aktualna nauka św. Tomasza z Akwinu przynosi antidotum na bolączki dręczące współczesnego człowieka. Powrót do realizmu i obiektywizmu poznawczego jako właściwego sposobu postrzegania rzeczywistości oraz akceptacja osoby Boga będącego autentycznym źródła prawa moralnego są drogami powrotu do odzyskania utraconej świadomości grzechu.

Słowa klucze: grzech, relatywizm, moralność, prawo naturalne, świadomość, natura

\section{Saint Thomas Aquinas' Answer to the Contemporary Loss of the Consciousness of Sin}

\section{Summary}

Currently, especially in Europe, we are dealing with progressive and rapidly deepening secularization. As a result, the sources of morality, i.e., family, school, and the Church have gradually begun to lose their authoritative significance. This, in turn, leads to extremely subjective attitudes. Therefore, the loss of the consciousness of $\sin$ is another consequence of the above-mentioned processes. The sources of the moral anesthesia are the deepening crisis of faith, the domination of subjective attitudes, and a wrong concept of the Church. Contemporary man ceases to seek the unchanging moral norms that have shaped European societies for centuries, because he himself wants to become their only source and determinant.

The still valid teaching of St. Thomas Aquinas brings us an antidote to the illnesses that torment modern man. The return to realism and cognitive objectivity, as the correct way of perceiving reality and the acceptance of the person of God as the authentic source of the moral law are the best ways of regaining the lost consciousness of $\sin$.

Key words: sin, relativism, morality, natural law, awareness, nature 